\title{
Paracoccus alcaliphilus sp. nov., an Alkaliphilic and Facultatively Methylotrophic Bacterium
}

\author{
TEIZI URAKAMI, ${ }^{1 *}$ JIN TAMAOKA, ${ }^{2}$ KEN-ICHIRO SUZUKI,${ }^{3}$ AND KAZUO KOMAGATA ${ }^{2}$ \\ Niigata Research Laboratory, Mitsubishi Gas Chemical Co., Tayuhama, Niigata 950-31, Japan ${ }^{1}$; Institute of Applied \\ Microbiology, The University of Tokyo, Bunkyo-ku, Tokyo 113, Japan ${ }^{2}$; and Japan Collection of Microorganisms, The \\ Institute of Physical and Chemical Research, Wako-shi, Saitama 351-01, Japan ${ }^{3}$
}

\begin{abstract}
Alkaliphilic facultatively methanol-utilizing bacteria were investigated with respect to their phenotypic and chemotaxonomic characteristics. These bacteria were gram-negative, nonsporeforming, nonmotile, coccoid or short rod-shaped organisms, grew at pH 7.0 to 9.5, and did not grow below pH 6.5 and above pH 10.0. The deoxyribonucleic acid (DNA) base composition was 64 to $66 \mathrm{~mol} \%$ guanine plus cytosine. These bacteria resemble Paracoccus denitrificans with respect to morphological and chemotaxonomic characteristics, but are distinguished from $P$. denitrificans by physiological characteristics and DNA-DNA homology. These methanolutilizing bacteria are described as a new species, Paracoccus alcaliphilus Urakami, Tamaoka, Suzuki, and Komagata. The type strain of $P$. alcaliphilus sp. nov. is strain TK 1015 (= JCM 7364).
\end{abstract}

Previously, we $(15,16,18,19)$ reported the grouping of gram-negative, methanol-utilizing bacteria on the basis of morphological characteristics, utilization of carbon compounds, deoxyribonucleic acid (DNA) base composition, cellular fatty acid composition, hydroxy fatty acid composition, ubiquinone system, occurrence of squalene and steroids, and electrophoretic properties of enzymes and divided these bacteria into 11 groups.

The group 10 methanol-utilizing bacteria and the group 8 methanol-utilizing bacteria that we described $(15,16,18,19)$ are facultatively methylotrophic, nonsporeforming, gramnegative, nonmotile, coccoid or short rod-shaped organisms with a Q-10 ubiquinone system, a cellular fatty acid composition consisting of a large amount of $C_{18: 1}$ acid (type $B$ ), and a hydroxy fatty acid composition consisting of a large amount of 3-OH $\mathrm{C}_{10: 0}$ acid and 3-OH $\mathrm{C}_{14: 0}$ acid. However, these two groups are distinguished from each other by the $\mathrm{pH}$ range for growth and DNA-DNA homologies. The group 8 bacteria have previously been identified as Paracoccus denitrificans $(8,15,16,18,19) . P$. denitrificans strains do not grow under alkaline conditions, but the group 10 methanolutilizing bacteria grow even at $\mathrm{pH} 9.0$.

In this study we characterized the group 10 methanolutilizing bacteria and Paracoccus strains and established a new species, Paracoccus alcaliphilus, for the group 10 methanol-utilizing bacteria.

\section{MATERIALS AND METHODS}

Bacterial strains. The strains which we studied are shown in Table 1. The group 10 bacteria were maintained on medium $\mathrm{D}(\mathrm{pH} 9.0)(15)$. $P$. denitrificans strains were maintained on medium B (15) or PYG agar medium containing $0.5 \%$ peptone, $0.5 \%$ yeast extract, $0.5 \%$ glucose, and $0.2 \%$ agar; this medium was adjusted to $\mathrm{pH} 7.0$ with $1 \mathrm{~N} \mathrm{NaOH}$.

Identification methods. Medium D agar (pH 9.0) (15) containing methanol was used for the group 10 bacteria. Medium B agar ( $\mathrm{pH} 7.1$ ) (15) containing methanol and PYG agar medium were used for preculture and basal media for $P$. denitrificans strains. Unless otherwise stated, the strains were cultivated at $30^{\circ} \mathrm{C}$. Cell form, Gram reaction, and motility were determined by using cells grown on each basal

\footnotetext{
* Corresponding author.
}

medium. Granules of poly- $\beta$-hydroxybutyrate in cells cultivated in medium containing $0.5 \%$ (wt/vol) $D L-\beta$-hydroxy$n$-butyric acid (sodium salt) were stained by the method of Burdon (3). Biochemical and physiological characteristics were examined for comparison with other aerobic bacteria by using previously described methods $(14,17)$. Media adjusted to $\mathrm{pH} 9.0$ with a $10 \% \mathrm{Na}_{2} \mathrm{CO}_{3}$ solution were used for the group 10 bacteria. Utilization of carbon compounds was determined in liquid basal medium B or medium D, and methanol or D-glucose was replaced with other carbon compounds as previously described (17).

DNA base composition. Cells cultivated in each of the basal media at $30^{\circ} \mathrm{C}$ for 2 to 3 days with shaking were used for the DNA analysis. DNA was extracted by using the method of Saito and Miura (10), and the guanine-plus-cytosine $(\mathrm{G}+\mathrm{C})$ content was determined by reverse-phase high-performance liquid chromatography as described by Tamaoka and Komagata (13).

DNA-DNA hybridization. DNA-DNA hybridization was carried out at $61^{\circ} \mathrm{C}$ by using the method of Kaneko et al. (7). DNAs from isolate TK $1015^{\mathrm{T}}(\mathrm{T}=$ type strain $)$ of the group 10 methanol-utilizing bacteria and $P$. denitrificans ATCC $17441^{\mathrm{T}}$ were labeled with $\left[1^{\prime}, 2^{\prime}, 5-{ }^{3} \mathrm{H}\right]$-deoxycytidine triphosphate by using the nick translation method and kit TRK 700 (Amersham International plc, Amersham, United Kingdom). DNA-DNA hybridizations were carried out with three strains of group 10 methanol-utilizing bacteria and three strains of $P$. denitrificans.

\section{RESULTS}

Phenotypic characteristics of the group 10 bacteria. Phenotypic characteristics of the group 10 bacteria are shown in Tables 2 and 3 . All of the strains were gram negative, nonsporeforming, nonmotile, coccoid or short rod-shaped organisms, measuring 0.6 to $1.0 \mu \mathrm{m}$ in diameter and 0.8 to $2.0 \mu \mathrm{m}$ long. Granules of poly- $\beta$-hydroxybutyric acid accumulated in the cells. Colonies were white or light yellow on medium $\mathrm{D}$ ( $\mathrm{pH}$ 9.0). Poor growth in nutrient broth and peptone water was observed. A water-soluble fluorescent pigment was not produced on King A and King B media adjusted to $\mathrm{pH} 9.0$. Nitrate was reduced to nitrite. The Voges-Proskauer test in glucose phosphate broth (12) adjusted to $\mathrm{pH} 9.0$ was negative. Production of indole in $1 \%$ tryptone broth adjusted to $\mathrm{pH} 9.0$ and production of hydro- 
TABLE 1. Bacterial strains studied

\begin{tabular}{|c|c|c|}
\hline Strain & Other strain designations ${ }^{a}$ & Reference(s) \\
\hline \multicolumn{3}{|l|}{ Group 10 methanol-utilizing bacteria } \\
\hline Isolate TK 1001 & Urakami 0-3 & \\
\hline Isolate TK 1002 & Urakami 0-9 & \\
\hline Isolate TK 1003 & Urakami 0-13 & \\
\hline Isolate TK 1004 & Urakami 0-17 & \\
\hline Isolate TK 1005 & Urakami 0-19 & \\
\hline Isolate TK 1006 & Urakami $0-20$ & \\
\hline Isolate TK 1007 & Urakami $0-74$ & \\
\hline Isolate TK 1008 & Urakami $0-75$ & \\
\hline Isolate TK 1009 & Urakami 0-78 & \\
\hline Isolate TK 1010 & Urakami $0-83$ & \\
\hline Isolate TK 1011 & Urakami $0-88$ & \\
\hline Isolate TK 1012 & Urakami $0-89$ & \\
\hline Isolate TK 1013 & Urakami $0-90$ & \\
\hline Isolate TK 1014 & Urakami $0-91$ & \\
\hline Isolate TK $1015^{\mathrm{T}}$ & Urakami $0-100$ & \\
\hline \multicolumn{3}{|l|}{ Group 8 methanol-utilizing bacteria } \\
\hline$P$. denitrificans ATCC $17441^{\mathrm{T}}$ & DSM $65^{\mathrm{T}}$, IAM $12479^{\mathrm{T}}, \mathrm{NCIB} 11627^{\mathrm{T}}$ & 4,11 \\
\hline P. denitrificans ATCC 13543 & CCM 982, NRRL 3784 & 4,20 \\
\hline P. denitrificans IFO 13301 & ATCC 19367, DSM 413, NCIB 8944, NRRL 3785 & 4,20 \\
\hline P. denitrificans NCIB 9722 & CCM 1396, DSM 415 & 4,20 \\
\hline P. denitrificans DSM 1403 & & 9 \\
\hline P. denitrificans DSM 1404 & & 9 \\
\hline P. denitrificans DSM 1405 & & 9 \\
\hline P. denitrificans DSM 1406 & & 9 \\
\hline P. denitrificans DSM 1407 & & 9 \\
\hline P. denitrificans DSM 1408 & & 9 \\
\hline P. denitrificans IFO 12442 & & 6 \\
\hline
\end{tabular}

a Abbreviations for culture collections: ATCC, American Type Culture Collection, Rockville, Md.; CCM, Czechoslovak Collection of Microorganisms, J. E. Purkyne University, Brno, Czechoslovakia; DSM, Deutsche Sammlung von Mikroorganismen, Gottingen, Federal Republic of Germany; FERM, Fermentation Research Institute, Agency of Industrial Science and Technology, Tukuba, Japan; IAM, Institute of Applied Microbiology, University of Tokyo, Tokyo, Japan; IFO, Institute for Fermentation, Osaka, Japan; NCIB, National Collection of Industrial Bacteria, Aberdeen, United Kingdom; NRRL, Agricultural Research Service Culture Collection, Northern Regional Research Center, Peoria, Ill.

gen sulfide (TSI medium adjusted to $\mathrm{pH}$ 9.0) were not observed. Hydrolysis of gelatin and starch was not observed. (PYG medium adjusted to $\mathrm{pH} 9.0$ was used as a basal medium.) Production of ammonia in peptone water adjusted to $\mathrm{pH} 9.0$ was positive.

Denitrification on PYG agar containing $0.3 \%$ (wt/vol) $\mathrm{KNO}_{3}$ and adjusted to $\mathrm{pH} 9.0$ and denitrification on medium $\mathrm{B}$ in which $\left(\mathrm{NH}_{4}\right)_{2} \mathrm{SO}_{4}$ was replaced with $0.3 \%(\mathrm{wt} / \mathrm{vol})$ $\mathrm{KNO}_{3}$ were negative. Litmus milk was not changed. All of the strains grew at the expense of $\mathrm{L}$-arabinose, D-xylose, D-glucose, D-mannose, D-fructose, galactose, D-sorbitol, D-mannitol, inositol, glycerol, succinic acid, citric acid, acetic acid, ethanol, and methanol, but did not grow at the expense of maltose, sucrose, lactose, trehalose, soluble starch, formic acid, dimethylamine, trimethylamine, methane, and hydrogen. Most strains grew at the expense of monomethylamine, but two strains did not, as shown in Table 3. Biotin was required. Ammonia, nitrate, urea, and peptone were utilized by all of the strains as nitrogen sources. Urease, oxidase, and catalase were produced. Growth was observed between $\mathrm{pH} 7.0$ and 9.5 , but not below $\mathrm{pH} 6.5$ and above $\mathrm{pH} 10.0$. The optimum cultural $\mathrm{pH}$ was $\mathrm{pH}$ 8.0 to 9.0 . All of the strains grew at $30^{\circ} \mathrm{C}$, but did not grow at $37^{\circ} \mathrm{C}$. All of the strains grew weakly in the presence of $3 \%$ sodium chloride.

Phenotypic characteristics of $\boldsymbol{P}$. denitrificans. Phenotypic characteristics of $\boldsymbol{P}$. denitrificans strains are shown in Tables 2 through 4 . All of the strains were gram-negative, nonsporeforming, nonmotile, coccoid (diameter, 0.5 to $0.9 \mu \mathrm{m}$ ) or short rod-shaped (length, 0.9 to $2.0 \mu \mathrm{m}$ ) organisms. Granules of poly- $\beta$-hydroxybutyric acid accumulated in the cells.
Colonies were white to light yellow on PYG medium and medium B. Growth in nutrient broth and peptone water was abundant. A water-soluble fluorescent pigment was not produced on King A and King B media. Nitrate was reduced to nitrite. The methyl red test and Voges-Proskauer test were negative. Indole and hydrogen sulfide were not produced. Hydrolysis of gelatin and starch was not observed. Ammonia was produced. Denitrification was performed. Litmus milk was not changed. Table 4 shows the oxidative production of acid from sugars. Acid was not produced fermentatively. All of the strains grew at the expense of D-glucose, D-mannose, D-fructose, trehalose, D-sorbitol, mannitol, inositol, succinic acid, acetic acid, ethanol, and hydrogen, but did not grow at the expense of D-xylose, lactose, soluble starch, formic acid, dimethylamine, trimethylamine, and methane. Most strains grew at the expense of L-arabinose, galactose, maltose, sucrose, glycerol, citric acid, methanol, and monomethylamine, but some strains did not, as shown in Table 3. Vitamins and amino acids were not required. Ammonia and peptone were utilized by all of the strains as nitrogen sources. Most strains utilized nitrate and urea as nitrogen sources, but some strains did not, as shown in Table 2. Urease, oxidase, and catalase were produced. Growth was observed between $\mathrm{pH} 6.0$ and 8.0 , but not at $\mathrm{pH}$ 5.0 and 9.0. The optimum cultural $\mathrm{pH}$ was between $\mathrm{pH} 6.5$ and 7.5. All of the strains grew at 30 and $37^{\circ} \mathrm{C}$, but did not grow at $47^{\circ} \mathrm{C}$. Some strains grew at $42^{\circ} \mathrm{C}$. Growth did not occur in the presence of $3 \%(\mathrm{wt} / \mathrm{vol}) \mathrm{NaCl}$.

DNA base composition. DNA base compositions are shown in Table 5. The DNA base compositions of the group 10 methanol-utilizing bacteria ranged from 64 to $66 \mathrm{~mol} \% \mathrm{G}+\mathrm{C}$, 
TABLE 2. Biochemical and physiological characteristics of the group 10 methanol-utilizing bacteria and $P$. denitrificans strains

\begin{tabular}{|c|c|c|c|c|c|c|c|c|c|c|c|c|c|c|c|c|c|c|}
\hline \multirow[b]{2}{*}{ Strain } & \multirow{2}{*}{ 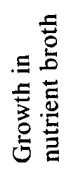 } & \multirow{2}{*}{ 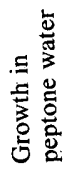 } & \multirow[b]{2}{*}{ 总总 } & \multirow{2}{*}{ 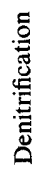 } & \multirow{2}{*}{ 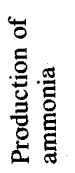 } & \multirow{2}{*}{ 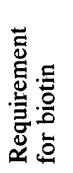 } & \multirow{2}{*}{ 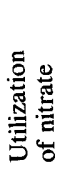 } & \multirow[b]{2}{*}{ 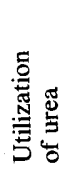 } & \multicolumn{3}{|c|}{$\begin{array}{c}\text { Growth in the presence } \\
\text { of: }\end{array}$} & \multicolumn{7}{|c|}{ Growth at: } \\
\hline & & & & & & & & & $\begin{array}{c}0 \\
\mathrm{NaCl}\end{array}$ & $\begin{array}{c}3 \% \\
\text { (wt/vol) } \\
\mathrm{NaCl}\end{array}$ & $\begin{array}{c}6 \% \\
\text { (wt/vol) } \\
\mathrm{NaCl}\end{array}$ & $\underset{6}{\mathrm{pH}}$ & $\begin{array}{c}\mathrm{pH} \\
7\end{array}$ & $\begin{array}{c}\mathrm{pH} \\
8\end{array}$ & $\begin{array}{c}\mathrm{pH} \\
9\end{array}$ & $30^{\circ} \mathrm{C}$ & $37^{\circ} \mathrm{C}$ & $42^{\circ} \mathrm{C}$ \\
\hline Isolate TK 1001 & $\mathrm{w}^{a}$ & - & w & - & + & + & + & + & + & w & - & - & w & + & + & + & - & - \\
\hline Isolate TK 1002 & w & w & + & - & + & + & + & + & + & w & - & - & w & + & + & + & - & - \\
\hline Isolate TK 1003 & w & w & w & - & + & + & + & + & + & $w$ & - & - & w & + & + & + & - & - \\
\hline Isolate TK 1004 & $w$ & w & + & - & + & + & + & + & + & w & - & - & $\mathbf{w}$ & + & + & + & - & - \\
\hline Isolate TK 1005 & w & w & + & - & + & + & + & + & + & w & - & - & w & + & + & + & - & - \\
\hline Isolate TK 1006 & w & - & $w$ & - & + & + & + & + & + & w & - & - & w & + & + & + & - & - \\
\hline Isolate TK 1007 & $w$ & - & + & - & + & + & + & + & + & w & - & - & $w$ & + & + & + & - & - \\
\hline Isolate TK 1008 & w & w & + & - & + & + & + & + & + & w & - & - & w & + & + & + & - & - \\
\hline Isolate TK 1009 & w & $\mathrm{w}$ & + & - & + & + & + & + & + & w & - & - & w & + & + & + & - & - \\
\hline Isolate TK 1010 & w & - & + & - & + & + & + & + & + & w & - & - & w & + & + & + & - & - \\
\hline Isolate TK 1011 & $w$ & w & + & - & + & + & + & + & + & w & - & - & w & + & + & + & - & - \\
\hline Isolate TK 1012 & w & w & + & - & + & + & + & + & + & w & - & - & $w$ & + & + & + & - & - \\
\hline Isolate TK 1013 & w & - & + & - & + & + & + & + & + & w & - & - & w & + & + & + & - & - \\
\hline Isolate TK 1014 & $w$ & - & + & - & + & + & + & + & + & w & - & - & w & + & + & + & - & - \\
\hline Isolate $\mathrm{TK} 1015^{\mathrm{T}}$ & $\mathrm{w}$ & w & + & - & + & + & + & + & + & w & - & - & w & + & + & + & - & - \\
\hline P. denitrificans ATCC $17441^{\mathrm{T}}$ & + & + & + & + & + & - & w & + & + & - & - & + & + & + & - & + & + & - \\
\hline P. denitrificans ATCC 13543 & + & + & + & + & + & - & + & + & + & - & - & + & + & + & - & + & + & - \\
\hline P. denitrificans IFO 13301 & + & + & + & + & + & - & + & + & + & - & - & + & + & + & - & + & + & - \\
\hline P. denitrificans NCIB 9722 & + & + & + & + & + & - & + & + & + & - & - & + & + & + & - & + & + & - \\
\hline P. denitrificans DSM 1403 & + & + & + & + & + & - & + & + & + & - & - & + & + & + & - & + & + & - \\
\hline P. denitrificans DSM 1404 & + & + & + & + & + & - & + & - & + & - & - & + & + & + & - & + & + & - \\
\hline P. denitrificans DSM 1405 & + & + & + & + & + & - & - & - & + & - & - & + & + & + & - & + & + & - \\
\hline P. denitrificans DSM 1406 & + & + & + & + & + & - & + & + & + & - & - & + & + & + & - & + & + & - \\
\hline P. denitrificans DSM 1407 & + & + & + & + & + & - & - & - & + & - & - & + & + & + & - & + & + & - \\
\hline P. denitrificans DSM 1408 & + & + & + & + & + & - & + & + & + & - & - & + & + & + & - & + & + & - \\
\hline P. denitrificans IFO 12442 & + & + & + & + & + & - & + & - & + & - & - & + & + & + & - & + & + & - \\
\hline
\end{tabular}

${ }^{a}+$, Positive; - , negative; $w$, weakly positive.

and the DNA base compositions of $P$. denitrificans strains ranged from 65 to $68 \mathrm{~mol} \% \mathrm{G}+\mathrm{C}$.

DNA-DNA homologies. The levels of DNA-DNA homology among the group 10 methanol-utilizing bacteria and $P$. denitrificans strains indicate a clear separation of these bacteria (Table 6). Furthermore, three strains of group 10 methanol-utilizing bacteria showed high levels of similarity to each other, as did three strains of $P$. denitrificans. The DNAs of the group 10 methanol-utilizing bacteria hybridized to the $P$. denitrificans strain DNAs at values of 30 to $60 \%$.

\section{DISCUSSION}

The group 10 methanol-utilizing bacteria grew at $\mathrm{pH} 7.0$ to 9.5 , and this characteristic is unique in the methanol-utilizing bacteria. They shared almost the same phenotypic characteristics, as well as the same cellular fatty acid composition (16), hydroxy fatty acid composition (16), ubiquinone system (15), and DNA base composition. The strains which we studied showed high levels of similarity to each other in DNA-DNA hybridizations. Therefore, these bacteria fall into a single taxon. These bacteria resembled $P$. denitrificans in morphological characteristics and chemotaxonomic characteristics. Furthermore, these bacteria exhibited less than $44 \%$ DNA-DNA homology with $P$. denitrificans strains. On the other hand, the type strain of $P$. denitrificans exhibited less than 58\% DNA-DNA homology with the group 10 isolates. The discrepancy in DNA-DNA homology results between the group 10 bacteria and $P$. denitrificans is not clear. Therefore, the group 10 alkaliphilic facultatively methylotrophic bacteria seem to be members of the genus Paracoccus. We propose a new species, $P$. alcaliphilus, for the group 10 bacteria. The type strain of $P$. alcaliphilus is strain TK 1015. The minimal characteristics for differentiating $P$. alcaliphilus from $P$. denitrificans are shown in Table 7 .

$P$. denitrificans strains share almost the same phenotypic characteristics, as well as the same cellular fatty acid composition (16), hydroxy fatty acid composition (16), ubiquinone system (15), and DNA base composition. Utilization of methanol was different among the strains, and five strains (DSM 1403, DSM 1404, DSM 1405, DSM 1407, and DSM 1408) did not utilize methanol, as shown by Nokhal and Schlegel (9). Auling et al. (1) reported three clusters, the strain $S^{\mathrm{T}}$ (= ATCC $17441^{\mathrm{T}}$ ) group, the strain M (= DSM 413 $=$ IFO 13301) group, and the strain N4 (= DSM 1404) group, based on a DNA-DNA hybridization study. However, in this study three strains (strains ATCC $17441^{\mathrm{T}}$, DSM 1404, and DSM 1405) showed high levels of similarity in DNA-DNA hybridization experiments. Therefore, these group 8 bacteria fall into a single taxon, $P$. denitrificans, as reported by Nokhal and Schlegel (9).

Description of Paracoccus alcaliphilus Urakami, Tamaoka, Sużuki, and Komagata sp. nov. Paracoccus alcaliphilus (al.cal.i.phil'us. M.L. alcali, Eng. alkali from the Arabic al, the end, and qaliy, soda ash; Gr.adj.phila, loving; M.L. adj. alcaliphilus, with an affinity for alkalinity [i.e., alkaline media]). Coccoid cells (diameter, 0.5 to $0.9 \mu \mathrm{m}$ ) or short rods (length, 0.9 to $2.0 \mu \mathrm{m}$ ) occur singly, in pairs, or in clusters. Colonies are white to light yellow. Gram-negative. Nonmotile. Granules of poly- $\beta$-hydroxybutyric acid accumulate in the cells. Growth in nutrient broth is very poor, but growth in nutrient broth adjusted to pH 9.0 is abundant. Growth in peptone water is poor or nonexistent (Table 2), but growth in 
TABLE 3. Utilization of carbon compounds by the group 10 methanol-utilizing bacteria and $P$. denitrificans strains

\begin{tabular}{|c|c|c|c|c|c|c|c|c|c|c|c|c|c|c|c|c|c|}
\hline \multirow[b]{2}{*}{ Strain } & \multicolumn{17}{|c|}{ Utilization of: } \\
\hline & 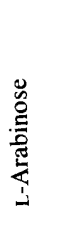 & $\begin{array}{l}\stackrel{y}{0} \\
\stackrel{0}{\lambda} \\
\dot{a} \\
\dot{a}\end{array}$ & 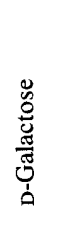 & 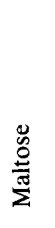 & 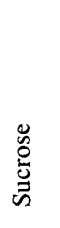 & 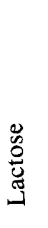 & 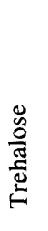 & 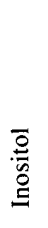 & $\begin{array}{l}\overline{0} \\
\stackrel{0}{0} \\
\frac{2}{0}\end{array}$ & 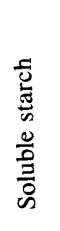 & 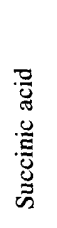 & 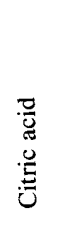 & 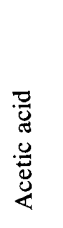 & 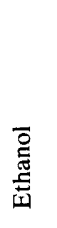 & 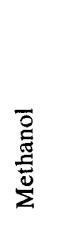 & 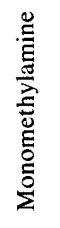 & 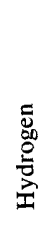 \\
\hline Isolate TK 1001 & $+^{a}$ & + & + & - & - & - & - & + & + & - & + & + & + & + & + & + & - \\
\hline Isolate TK 1002 & + & + & + & - & - & - & - & + & + & - & + & + & w & + & + & + & - \\
\hline Isolate TK 1003 & + & + & + & - & - & - & - & + & $\mathrm{w}$ & - & + & + & w & + & + & + & - \\
\hline Isolate TK 1004 & + & + & + & - & - & - & - & + & $\mathrm{w}$ & - & + & + & w & + & + & + & - \\
\hline Isolate TK 1005 & + & + & + & - & - & - & - & + & $\mathrm{w}$ & - & + & + & w & + & + & + & - \\
\hline Isolate TK 1006 & + & + & + & - & - & - & - & + & $w$ & - & + & + & w & + & + & - & - \\
\hline Isolate TK 1007 & + & + & + & - & - & - & - & + & $\mathrm{w}$ & - & + & + & $w$ & + & + & + & - \\
\hline Isolate TK 1008 & + & + & + & - & - & - & - & + & w & - & + & + & + & $\mathrm{w}$ & + & - & - \\
\hline Isolate TK 1009 & + & + & + & - & - & - & - & + & $w$ & - & + & + & w & + & + & + & - \\
\hline Isolate TK 1010 & + & + & + & - & - & - & - & + & $w$ & - & + & + & $w$ & + & + & + & - \\
\hline Isolate TK 1011 & + & + & + & - & - & - & - & + & w & - & + & + & + & + & + & + & - \\
\hline Isolate TK 1012 & + & + & + & - & - & - & - & + & w & - & + & + & + & + & + & + & - \\
\hline Isolate TK 1013 & + & + & + & - & - & - & - & + & w & - & + & + & w & + & + & + & - \\
\hline Isolate TK 1014 & + & + & + & - & - & - & - & + & $\mathrm{w}$ & - & + & + & $w$ & w & + & + & - \\
\hline Isolate TK $1015^{\mathrm{T}}$ & + & + & + & - & - & - & - & + & $\mathrm{w}$ & - & + & + & + & + & + & + & - \\
\hline P. denitrificans ATCC $17441^{\mathrm{T}}$ & - & - & - & + & + & - & + & + & + & - & + & - & + & + & + & - & + \\
\hline P. denitrificans ATCC 13543 & + & - & + & + & + & - & + & + & + & - & + & + & + & + & + & + & + \\
\hline P. denitrificans IFO 13301 & + & - & + & + & + & - & + & + & + & - & + & + & + & + & + & + & + \\
\hline P. denitrificans NCIB 9722 & + & - & + & + & + & - & + & + & + & - & + & + & + & + & + & + & + \\
\hline P. denitrificans DSM 1403 & + & - & + & + & + & - & + & + & - & - & + & + & + & + & - & + & + \\
\hline P. denitrificans DSM 1404 & + & - & + & + & + & - & + & + & + & - & + & + & + & + & - & + & + \\
\hline P. denitrificans DSM 1405 & + & - & + & + & + & - & + & + & + & - & + & + & + & + & - & + & + \\
\hline P. denitrificans DSM 1406 & + & - & + & + & + & - & + & + & + & - & + & + & + & + & + & + & + \\
\hline P. denitrificans DSM 1407 & + & - & + & + & - & - & + & + & + & - & + & + & + & + & - & + & + \\
\hline P. denitrificans DSM 1408 & + & - & + & - & - & - & + & + & + & - & + & - & + & + & - & + & + \\
\hline$P$. denitrificans IFO 12442 & + & - & + & + & + & - & + & + & + & - & + & - & + & + & + & + & + \\
\hline
\end{tabular}

$a_{+}$, Positive; -, negative; w, weakly positive.

peptone water adjusted to $\mathrm{pH} 9.0$ is abundant. A watersoluble fluorescent pigment is not produced. Nitrate is reduced to nitrite. The Voges-Proskauer test is negative. Indole and hydrogen sulfide are not produced. Hydrolysis of gelatin and starch is not observed. Ammonia is produced. Denitrification is not performed. Litmus milk is not changed. L-Arabinose, D-xylose, D-glucose, D-mannose, D-fructose,
D-galactose, D-sorbitol, D-mannitol, inositol, glycerol, succinic acid, citric acid, acetic acid, ethanol, and methanol are utilized, but maltose, sucrose, lactose, trehalose, soluble starch, formic acid, dimethylamine, trimethylamine, methane, and hydrogen are not utilized. Utilization of monomethylamine differs among the strains. Biotin is required as an essential supplement. Ammonia, nitrate, urea, and peptone

TABLE 4. Oxidative production of acid from sugars by $P$. denitrificans strains

\begin{tabular}{|c|c|c|c|c|c|c|c|c|c|c|c|c|c|c|c|}
\hline \multirow[b]{2}{*}{$\begin{array}{l}P . \text { denitrificans } \\
\text { strain }\end{array}$} & \multicolumn{15}{|c|}{ Oxidation of: } \\
\hline & 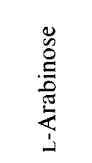 & 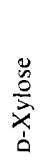 & $\begin{array}{l}0 \\
0 \\
0 \\
0 \\
\vdots \\
0\end{array}$ & 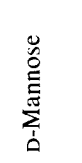 & 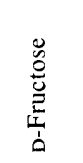 & 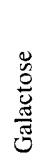 & $\frac{\mathscr{0}}{\stackrel{0}{\frac{\pi}{3}}}$ & 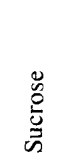 & 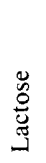 & 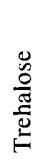 & $\begin{array}{l}\overline{0} \\
\stackrel{0}{0} \\
\overline{0} \\
\stackrel{0}{0} \\
\dot{0}\end{array}$ & 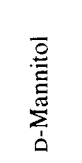 & $\begin{array}{l}\bar{O} \\
\stackrel{\mathscr{g}}{\mathscr{E}} \\
\underline{n}\end{array}$ & $\begin{array}{l}\overline{0} \\
\frac{\mathbb{Z}}{0}\end{array}$ & 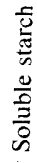 \\
\hline ATCC $17441^{\mathrm{T}}$ & $-a$ & - & + & $+(w)$ & + & - & + & + & - & + & + & + & + & + & - \\
\hline ATCC 13543 & + & - & + & $+(w)$ & + & + & + & + & - & + & + & + & + & + & - \\
\hline IFO 13301 & + & - & + & $+(w)$ & + & + & + & + & - & + & + & + & $+(w)$ & + & - \\
\hline NCIB 9722 & + & - & - & - & - & + & $+(w)$ & $+(w)$ & - & - & - & - & - & - & - \\
\hline DSM 1403 & $+(w)$ & - & - & - & - & - & - & - & - & - & - & $+(w)$ & - & - & - \\
\hline DSM 1404 & + & - & - & - & $+(w)$ & - & - & $+(w)$ & - & - & - & $+(w)$ & - & - & - \\
\hline DSM 1405 & + & - & - & - & - & - & + & $+(w)$ & - & - & - & $+(w)$ & - & - & - \\
\hline DSM 1406 & + & - & - & - & - & - & - & - & - & - & - & $+(w)$ & + & - & - \\
\hline DSM 1407 & + & - & + & + & + & + & + & + & - & - & + & + & + & + & - \\
\hline DSM 1408 & + & - & $+(w)$ & + & + & - & - & - & - & - & + & $+(w)$ & + & - & - \\
\hline IFO 12442 & + & - & + & $+(w)$ & + & + & + & + & - & + & + & + & - & + & - \\
\hline
\end{tabular}

$a+$, Positive; - , negative; $+(\mathrm{w})$, weak. 
TABLE 5. DNA base compositions of the group 10 methanolutilizing bacteria and $P$. denitrificans strains

\begin{tabular}{|c|c|c|}
\hline \multirow[b]{2}{*}{ Strain } & \multicolumn{2}{|c|}{$\mathrm{G}+\mathrm{C}$ content $(\mathrm{mol} \%)$} \\
\hline & This study & $\begin{array}{c}\text { Another } \\
\text { study }\end{array}$ \\
\hline Isolate TK 1001 & 64.1 & \\
\hline Isolate TK 1002 & 64.0 & \\
\hline Isolate TK 1003 & 64.6 & \\
\hline Isolate TK 1004 & 64.8 & \\
\hline Isolate TK 1005 & 64.5 & \\
\hline Isolate TK 1006 & 64.6 & \\
\hline Isolate TK 1007 & 64.6 & \\
\hline Isolate TK 1008 & 64.7 & \\
\hline Isolate TK 1009 & 64.8 & \\
\hline Isolate TK 1010 & 64.2 & \\
\hline Isolate TK 1011 & 64.4 & \\
\hline Isolate TK 1012 & 64.9 & \\
\hline Isolate TK 1013 & 65.5 & \\
\hline Isolate TK 1014 & 64.8 & \\
\hline Isolate TK $1015^{\mathrm{T}}$ & 64.4 & \\
\hline P. denitrificans ATCC $17441^{\mathrm{T}}$ & 66.9 & $66.3^{a}$ \\
\hline P. denitrificans ATCC 13543 & & $66.6^{b}$ \\
\hline P. denitrificans IFO 13301 & & $67.4^{c}$ \\
\hline P. denitrificans NCIB 9722 & & $67.0^{d}$ \\
\hline P. denitrificans DSM 1404 & 67.4 & $65.9^{b}$ \\
\hline P. denitrificans DSM 1405 & 67.2 & \\
\hline
\end{tabular}

${ }^{a}$ Data from reference 4 .

${ }^{b}$ Data from reference 18 .

c Data from reference 5 .

${ }^{a}$ Data from reference 2.

are utilized as nitrogen sources. Growth is observed between pH 7.0 and 9.5; no growth occurs below pH 6.5 and above $\mathrm{pH} 10.0$. The optimum cultural $\mathrm{pH}$ is $\mathrm{pH} 8.0$ to 9.0 . Growth is observed at $30^{\circ} \mathrm{C}$, but not at $37^{\circ} \mathrm{C}$. Growth in the presence of $3 \%$ sodium chloride is weak. Urease, oxidase, and catalase are produced. Aerobic. Metabolism is strictly respiratory and not fermentative. The DNA base composition ranges from 64 to $66 \mathrm{~mol} \% \mathrm{G}+\mathrm{C}$. The major cellular fatty acid is straight-chain unsaturated $\mathrm{C}_{18: 1}$ acid. The major hydroxy fatty acids are 3-hydroxy $\mathrm{C}_{10: 0}$ acid and 3-hydroxy $\mathrm{C}_{14: 0}$ acid. The major quinone is ubiquinone $\mathrm{Q}-10$, with $\mathrm{Q}-9$ and Q-11 as minor components.

Variations in phenotypic characteristics, DNA base composition, and DNA-DNA homology in the species are shown in Tables 2, 3, 5, and 6 .

The type strain is strain TK 1015.

Description of the type strain. Strain TK $1015^{T}$ has all of the characteristics given above for the species. In addition, this strain utilizes monomethylamine. Its DNA base composition is $64.4 \mathrm{~mol} \% \mathrm{G}+\mathrm{C}$. This strain was isolated from soil by $T$. Urakami (isolation number $0-100$ ). The type strain has

TABLE 6. DNA-DNA homologies among the group 10 methanolutilizing bacteria and $P$. denitrificans strains

\begin{tabular}{lcc}
\hline \multirow{2}{*}{\multicolumn{1}{c}{ Strain }} & \multicolumn{2}{c}{ \% DNA-DNA homology with: } \\
\cline { 2 - 3 } & $\begin{array}{c}\text { Strain } \\
\text { TK } 1015^{\mathrm{T}}\end{array}$ & $\begin{array}{c}\text { Strain } \\
\text { ATCC } 17441^{\mathrm{T}}\end{array}$ \\
\hline Isolate TK 1015 & 100 & 58 \\
Isolate TK 1001 & 81 & 57 \\
Isolate TK 1008 & 61 & 36 \\
$P$. denitrificans ATCC 17441 & 34 & 100 \\
$P$. denitrificans DSM 1404 & 31 & 77 \\
$P$. denitrificans DSM 1405 & 44 & 87 \\
\hline
\end{tabular}

TABLE 7. Differential characteristics of $P$. alcaliphilus and $P$. denitrificans

\begin{tabular}{|c|c|c|c|c|c|c|c|c|}
\hline \multirow[b]{2}{*}{ Species } & \multirow{2}{*}{ 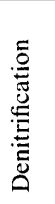 } & \multirow[b]{2}{*}{ 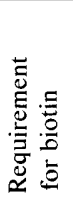 } & \multicolumn{2}{|c|}{$\begin{array}{l}\text { Growth } \\
\text { at: }\end{array}$} & \multicolumn{3}{|c|}{ Utilization of: } & \multirow{2}{*}{$\begin{array}{c}\mathrm{G}+\mathrm{C} \\
\text { content } \\
(\mathrm{mol} \%)\end{array}$} \\
\hline & & & $\begin{array}{c}\mathrm{pH} \\
6\end{array}$ & $\begin{array}{c}\mathrm{pH} \\
9\end{array}$ & 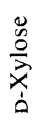 & 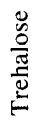 & 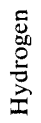 & \\
\hline P. alcaliphilus & $-a$ & + & - & + & + & - & - & $64-66$ \\
\hline$P$. denitrificans & + & - & + & - & - & + & + & $65-68$ \\
\hline
\end{tabular}

been deposited in the Japan Collection of Microorganisms, Institute of Physical and Chemical Research, as strain JCM 7364.

\section{LITERATURE CITED}

1. Auling, G., M. Dittbrenner, M. Maarzahl, T. Nokhal, and M. Reh. 1980. Deoxyribonucleic acid relationships among hydrogen-oxidizing strains of the genera Pseudomonas, Alcaligenes, and Paracoccus. Int. J. Syst. Bacteriol. 30:123-128.

2. Bohacek, J., M. Kocur, and T. Martinec. 1967. DNA base composition and taxonomy of some micrococci. J. Gen. Microbiol. 46:376-396.

3. Burdon, K. L. 1946. Fatty material in bacteria and fungi revealed by staining dried, fixed slide preparations. J. Bacteriol. 52:665-678.

4. Davis, D. H., M. Doudoroff, and R. Y. Stanier. 1969. Proposal to reject the genus Hydrogenomonas: taxonomic implications. Int. J. Syst. Bacteriol. 19:375-390.

5. De Smedt, J., M. Bauwens, R. Tytgat, and J. De Ley. 1980. Intraand intergeneric similarities of ribosomal ribonucleic acid cistrons of free-living, nitrogen-fixing bacteria. Int. J. Syst. Bacteriol. 30:102-122.

6. Iijima, T. (ed.). 1984. Institute for Fermentation, Osaka, list of cultures, 7 th ed. Institute for Fermentation, Osaka, Japan.

7. Kaneko, T., R. Nozaki, and K. Aizawa. 1978. Deoxyribonucleic acid relatedness between Bacillus anthracis, Bacillus cereus, and Bacillus thuringiensis. Microbiol. Immunol. 22:639-641.

8. Kocur, M. 1984. Genus Paracoccus Davis $1969,384^{\mathrm{AL}}$, p. 399 402. In N. R. Krieg and J. G. Holt (ed.), Bergey's manual of systematic bacteriology, vol. 1. The Williams \& Wilkins Co., Baltimore.

9. Nokhal, T., and H. Schlegel. 1983. Taxonomic study of Paracoccus denitrificans. Int. J. Syst. Bacteriol. 33:26-37.

10. Saito, J., and K. Miura. 1963. Preparation of transforming deoxyribonucleic acid by phenol treatment. Biochim. Biophys. Acta 72:619-629.

11. Skerman, V. B. D., V. McGowan, and P. H. A. Sneath (ed.) 1980. Approved lists of bacterial names. Int. J. Syst. Bacteriol. 30:225-420.

12. Smith, N. R., R. E. Gordon, and F. E. Clark. 1952. Aerobic sporeforming bacteria. Agricultural Monograph no. 16. United States Department of Agriculture, Washington, D.C.

13. Tamaoka, J., and K. Komagata. 1984. Determination of DNA base composition by reversed-phase high-performance liquid chromatography. FEMS Microbiol. Lett. 25:125-128.

14. Urakami, T., and K. Komagata. 1984. Protomonas, a new genus of facultatively methylotrophic bacteria. Int. J. Syst. Bacteriol. 34:188-201.

15. Urakami, T., and K. Komagata. 1986. Occurrence of isoprenoid compounds in gram-negative methanol-, methane-, and methylamine-utilizing bacteria. J. Gen. Appl. Microbiol. 32:317-341.

16. Urakami, T., and K. Komagata. 1987. Cellular fatty acid composition with special reference to the existence of hydroxy fatty acids in gram-negative methanol-, methane-, and methylamineutilizing bacteria. J. Gen. Appl. Microbiol. 33:135-165.

17. Urakami, T., and K. Komagata. 1987. Characterization of species of marine methylotrophs of the genus Methylophaga. 
Int. J. Syst. Bacteriol. 37:402-406.

18. Urakami, T., J. Tamaoka, and K. Komagata. 1985. DNA base composition and DNA-DNA homologies of methanol-utilizing bacteria. J. Gen. Appl. Microbiol. 31:243-253.

19. Urakami, T., I. Terao, and I. Nagai. 1981. Process for producing bacterial single cell protein from methanol, p. 349-359. In H. Dalton (ed.), Proceedings of the Third International Symposium on Microbial Growth on $\mathrm{C}_{1}$ Compounds. Heyden \& Son Ltd., London.

20. Verhoeven, W., A. L. Koster, and M. C. A. van Nievelt. 1954. Studies on true dissimilatory nitrate reduction. III. Micrococcus denitrificans Beikerinck, a bacterium capable of using molecular hydrogen in denitrification. Antonie van Leeuwenhoek J. Microbiol. Serol. 20:273-284. 